жение и расширенпе мағсимума отрипательного гальваномагнитного аффекта в случае сплавов. Более подробный разбор далее показал, что даже поликристаллический образеп электролитического никеля нельзя считать достаточно однородным и тто изучение закономерностей ферромагнитного перехода треб̆ует значительно более чистый и более определенный материал.

В заключение пршнопу свою благодарность Я. Кацеру и 3 . Фрайту, которые являлись оппонентами настоящей работы при ее обсужденип в институте и примечания которых епособетвовали ее уточнению.

Посту пило 25. 5. 1957.

\title{
MAGNETO-REESISTANCE CHANGE IN THE REGION OF THE CURIE POINT
}

\author{
(Abstract of preceding paper) \\ JAROSLAV PAČES \\ Institute of Physics, Czechosl. Acad. Sci., Prague
}

On the basis of relation (1), which was found experimentally [6], and relation (2), following from the thermodynamic theory of second order phase transformations [9], equations (5) and (6) were found, describing the isotherms of the magneto-resistance change in the region of the Curie point. The relations obtained are in good agroement with the experimental results for electrolytic nickel (Figs. 1-3) but do not correspond to the experimental results obtained for alloys. This disagreement is explained by the fact that alloys are not homogeneous from the magnetic point of view but that there exist in them components with various Curie points. Thus with alloys the transformation to the paramagnetic state does not take place at one temperature but is spread over a certain temperature interval. If we plot the values of the change in magnetoresistance corresponding to the same value of the external field as a function of the temperature, we obtain a curve which has its extreme in the region of the Curie point (Fig. 4). With alloys this extreme expands and decreases (Fig. 6). If we assume that the volumes corresponding to the individual components with various Curie points are subject to Gauss distribution (10) and that the course of the temperature dependence of the magnetoresistance change of a homogeneous material can be approximately deseribed by Eq. (12), we obtain relation (15). This relation is satisfactorily valid for nickel alloys with not too great admixtures of another element (Tab. 3). Better agreement could not be expected since Eq. (12) is only a very rough approximation (cf. Fig. 6). The graph of the dopendence of the magneto-resistance change on the square of the magnetization (Fig. 8) shows that even at a temperature of $350 \cdot 8^{\circ} \mathrm{C}$ spontaneous magnetization does not væaish in electrolytic nickel. In calculating the course of the isotherms it had however to be assumed that the Curie point of the nickel used lies at a temperature of $347.5^{\circ} \mathrm{C}$. This shows that not even electrolytic nickel was quite homogeneous.

Received 25. 5. 1957.

$$
\text { Tumepamypa - References }
$$

[1] Williams W. E.: Phil. Mag., 9 (1905), 77.

[2] Jenkins W. A.: Phil. Mag., 27 (1919), 731

[3] Gerlach W.: Zs. Phys. 59 (1930), 847.

[4] Gerlach W., Schneiderhahn K.: Ann. d. Phys. 6 (1930), 772.

[5] Potter H. H.: Phil. Mag. 13 (1932), 233

[6] Englert E.: Zs. Phys. 74 (1932), 748

[7] Белов R. П., Панин И. К,: ЖЭТФ 21 (1951), 809.

[8] Белов. K. П., Зайеша Г. A: ФМM 1 (1955), 404

[9] Гинбург В. Т.: ЖRэТФ 17 (1947), 833.

[10] Белов K. П., Горяга А. Н.: ФММ $2(1956), 3$. 